\title{
When Machines Take the Beans: Ex-Ante Socioeconomic Impact Evaluation of Mechanized Harvesting of Mungbean in Bangladesh and Myanmar
}

\author{
Lutz Depenbusch ${ }^{1, *(D)}$, Cathy Rozel Farnworth ${ }^{2}$, Pepijn Schreinemachers ${ }^{1}\left(\mathbb{D}\right.$, Thuzar Myint ${ }^{3}$, \\ Md Monjurul Islam ${ }^{4}{ }^{D}$, Nanda Dulal Kundu ${ }^{5}$ D, , Theingi Myint ${ }^{3}$, Aye Moe San ${ }^{3}$, Rownok Jahan ${ }^{6}$ \\ and Ramakrishnan Madhavan Nair ${ }^{7}$ (D)
}

Citation: Depenbusch, L.;

Farnworth, C.R.; Schreinemachers, P.; Myint, T.; Islam, M.M.; Kundu, N.D.; Myint, T.; San, A.M.; Jahan, R.; Nair, R.M. When Machines Take the Beans: Ex-Ante Socioeconomic Impact Evaluation of Mechanized Harvesting of Mungbean in Bangladesh and Myanmar. Agronomy 2021, 11, 925. https://doi.org/ 10.3390/agronomy11050925

Academic Editor: Piotr Prus

Received: 22 March 2021

Accepted: 27 April 2021

Published: 8 May 2021

Publisher's Note: MDPI stays neutra with regard to jurisdictional claims in published maps and institutional affiliations.

Copyright: (C) 2021 by the authors Licensee MDPI, Basel, Switzerland. This article is an open access article distributed under the terms and conditions of the Creative Commons Attribution (CC BY) license (https:// creativecommons.org/licenses/by/ $4.0 /)$
1 World Vegetable Center, P.O. Box 1010, Bangkok 10903, Thailand; pepijn.schreinemachers@worldveg.org

2 Pandia Consulting, 48145 Münster, Germany; cathyfarnworth@hotmail.com

3 Department of Agricultural Economics, Yezin Agricultural University, Nay Pyi Taw 15013, Myanmar; thetchanaye12@gmail.com (T.M.); dr.theingimyint@yau.edu.mm (T.M.); dr.ayemoesan@yau.edu.mm (A.M.S.)

4 Department of Rural Development, Faculty of Agricultural Economics and Rural Development, Bangabandhu Sheikh Mujibur Rahman Agricultural University, Gazipur 1706, Bangladesh; mmislam.rdv@bsmrau.edu.bd

5 Agricultural Economics Division, Regional Pulses Research Station, Bangladesh Agricultural Research Institute, Madaripur 7901, Bangladesh; nanda@bari.gov.bd

6 Independent Gender Consultant, Dhaka 1207, Bangladesh; jrownok@gmail.com

$7 \quad$ World Vegetable Center, ICRISAT Campus, Patancheru 502324, India; ramakrishnan.nair@worldveg.org

* Correspondence: Lutzdepenbusch@gmail.com

Abstract: Agricultural mechanization has spread across much of Asia since the 1960s. It has increased agricultural productivity and reduced arduous farm work. However, differing impacts for smallholders and hired laborers, and for men and women, require careful consideration. This study analyzed, ex-ante, the likely social and economic tradeoffs of mechanizing the mungbean harvest in Bangladesh and Myanmar. We used a mixed methods approach combining survey data from 852 farm households with in-depth interviews in four villages. Partial budget analysis shows that mechanical harvesting of mungbean is not yet profitable for most farms. There is nevertheless an incentive to mechanize as the associated timeliness of the harvest reduces the risk of harvest losses from weather shocks. Men and women farmers expect time savings and reduced drudgery. The results confirm that hired workers depend on manual harvesting for income and status in both countries. Most hired workers are landless married women with limited access to other sources of income. In the short term, farmers are likely to combine manual harvests and a final mechanized harvest of the indeterminate crop. This could mediate the impact on hired workers. However, in the long term, it will be necessary to facilitate income-generating opportunities for women in landless rural families to maintain their well-being and income.

Keywords: agricultural mechanization; rural employment; gender; pulses; mungbean

\section{Introduction}

Agriculture across South, East and Southeast Asia has gradually shifted from traditional labor-intensive production to mechanized labor-saving operations over the course of the past half century [1,2]. The systemic impacts of such mechanization processes of smallholder farm operations play out differently for smallholders and hired laborers [3]. On the one hand, the deployment of machinery saves farmers arduous manual work and promotes timeliness. These considerations can be particularly important in labor-intensive crops such as rice and mungbean [4]. The cost of hiring labor is generally increasing, for instance due to off-farm opportunities, better education among rural youth, increasing cost of living and increased negotiating power on the part of workers [5]. Since it reduces demand 
for family and hired labor, mechanization can free members of smallholder families to take up non-farm income-generating opportunities [6,7]. Ensuring multiple sources of household income contributes to the longevity of smallholder farms [6]. The mechanization of farm tasks associated with women in the local gender division of labor can free smallholder women to develop other enterprises, spend more time on other household tasks or get more time for rest and recreation, as well as generally experience a reduction in multi-tasking [8]. This is important because tasks often allocated to women, including weeding and harvesting, are frequently associated with drudgery. There may also be nutritional impacts as Singh et al. [9] found that women's energy expenditure balance was positive during sowing and weeding and negative during land preparation and harvesting. Nichols [10] found that, during peak work times, women did not eat sufficiently due to fatigue, work pressure and lack of time.

On the other hand, many lower-income countries experience continuing high rates of rural unemployment and underemployment [11] and mechanization may further aggravate these trends. Replacing labor through mechanization raises equity concerns $[12,13]$. Discussions turn on the question whether mechanization substitutes for laborers who are moving into other occupations, or whether it replaces laborers who would have preferred to keep their jobs [6]. Decisions are influenced by gender roles and practices, and the decisions taken themselves influence gender roles [14]. A key consideration is which women and which men are out-migrating. In Bangladesh, young women have long sought off-farm occupations, particularly in garment factories, but this trend has stalled since 2013 with ever more women remaining in the villages [15]. In Myanmar, young women also out-migrate, but married women often remain behind to care for children and elderly relatives [16]. Hiring out their labor can be particularly important as a livelihood strategy for women remaining in the village since they often have less access to, and control over, other assets which could be mobilized for income generation, and gender norms can mean that local off-farm opportunities for women may be limited [17,18]. An important consideration is whether farming systems built around a gender division of labor that foresees women undertaking some tasks, and men undertaking others, are able to adapt to changed demographics in the pool of potential hired labor. In Myanmar, farmers complain that "there are no more female transplanting or harvesting teams in the villages as we had before". However, women laborers complain that, due to mechanization, there is almost no paid work for them [19]. In Bangladesh, social biases against women laborers mean that they tend to be employed when men laborers are not available [20].

Our study focused on establishing the likely short-term effects of mechanized mungbean harvesting on farmer and hired labor incomes and wellbeing in Bangladesh and Myanmar. Field research was carried out between 2018 and 2020 as part of an Australian Center for International Agricultural Research (ACIAR) funded project "Improved Mungbean Harvesting and Seed Production Systems for Bangladesh, Myanmar and Pakistan" (https://www.aciar.gov.au/project/CIM-2016-174; accessed on 1 May 2021). The project is coordinated by the World Vegetable Center with key national partners being the Bangladesh Agricultural Research Institute, the Department of Agricultural Research in Myanmar and the Pakistan Agricultural Research Council. The aim is to establish a practical and economically viable system to mechanically harvest mungbeans using adapted combine harvesters on smallholder farms. Mungbean is produced by about 637,000 farm households in Myanmar and 151,000 farm households in Bangladesh [21].

We conducted a mixed-methods analysis to evaluate gender and other tradeoffs between the opportunities and risks of mechanizing the mungbean harvest. Our first research hypothesis was that mechanization reduces labor costs and thereby increases smallholder farm income. Second, we hypothesized that mechanized harvesting removes a source of drudgery from men and women in the farm household. Third, we hypothesized that mechanization eliminates an important income stream for hired women and men laborers. These hypotheses allow us to consider potential tradeoffs between the income of smallholder farms, the well-being of women smallholder famers and the well-being 
of women hired laborers. Well-being is understood here in a loose sense to describe respondent perceptions of having a good or meaningful life. These tradeoffs are expressed in Figure 1.

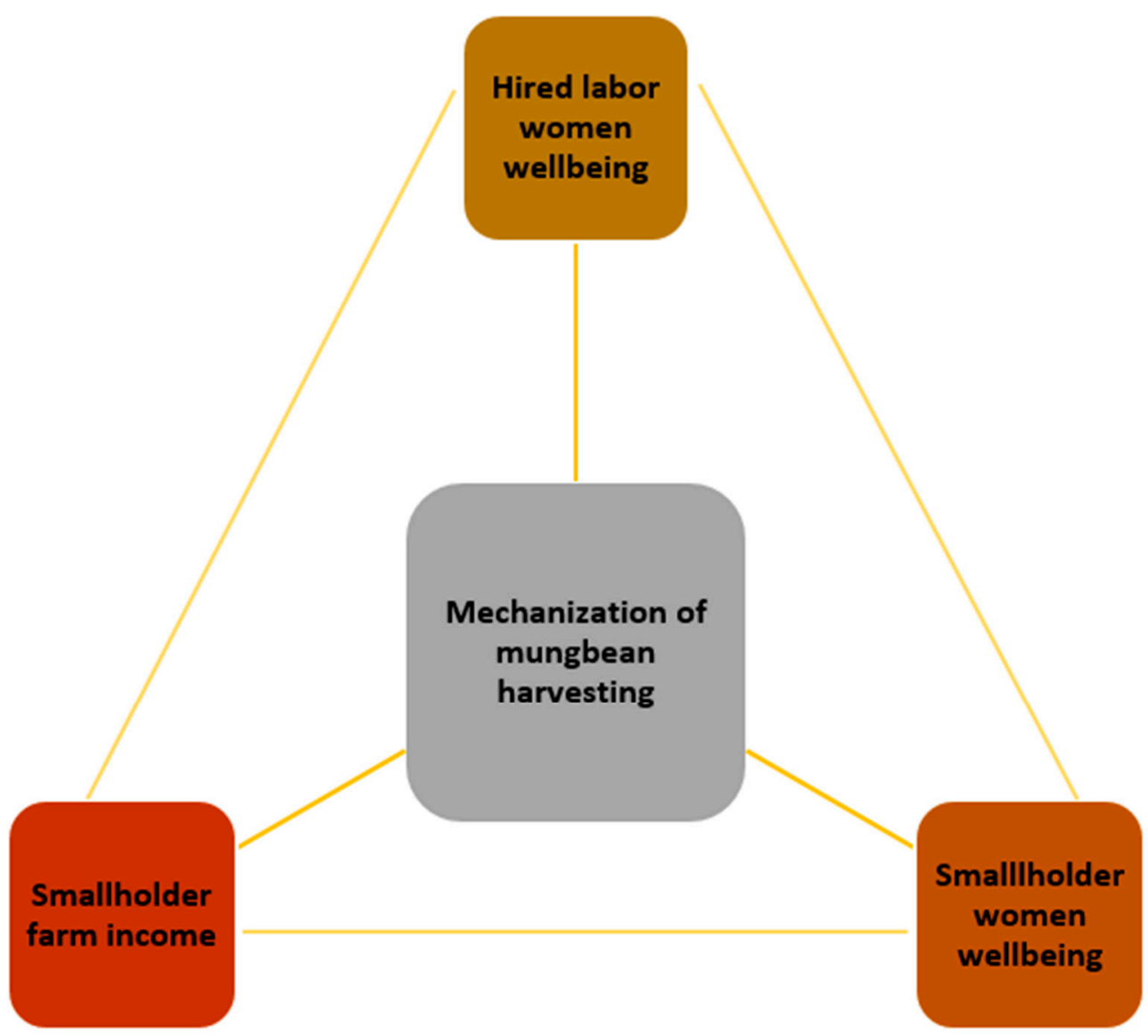

Figure 1. Potential gendered tradeoffs associated with mechanizing mungbean harvesting.

\subsection{Literature Review}

We now introduce the role of mungbean in farming systems in Bangladesh and Myanmar and explore mechanization processes. We then assess gendered findings regarding the costs and benefits of mechanizing farm tasks on smallholder and hired laborers.

\subsubsection{Mungbean in the Smallholder Farm System in Myanmar and Bangladesh}

Mungbean is a short duration crop, 70-90 days, which permits its easy integration into crop rotations. It contributes to healthy, climate-friendly diets by offering a highquality protein source with low greenhouse gas emissions [22-24]. In Bangladesh and lower Myanmar, mungbean is mostly grown in the hot and dry pre-monsoon season, while farmers in the central dry zone of Myanmar produce mungbean mostly during monsoon and winter season. Average mungbean yields are around 1.3 t/ha in Myanmar and 1.0 t/ha in Bangladesh [25]. The motivation for growing mungbean is very different in each country. In Bangladesh, it forms an important part of local diets as well as being sold. In Myanmar, it is not commonly eaten and about $92 \%$ of the crop output is sold to overseas markets [26].

Bangladesh and Myanmar are experiencing rapid agricultural mechanization. Starting in the 1980s and particularly since the 2000s, the supply of affordable small diesel engines, especially for irrigation, threshers and two-wheel tractors, has transformed Bangladesh's agriculture into one of the most mechanized in South Asia [27,28]. In Myanmar, agricultural mechanization has accelerated over the past decade. In the Central Dry Zone, for instance, mechanization was uncommon before 2008, but, by 2017, more than three quarters of 
households had mechanized at least part of their production [29]. In the Ayeyarwady Delta, the share of paddy farmers using machinery in land preparation jumped from 36\% in 2006 to $97 \%$ in 2016 and the share using combine harvesters jumped to $42 \%$ by 2016 after first being adopted in 2013 [30]. In both countries, scale-appropriate technology and widespread rental markets have resolved problems previously associated with the small size of most landholdings [27-29,31]. Changes in trade policy, access to credit and falling manufacturing costs have contributed to the increasing affordability of machinery $[27,29,30]$.

In mungbean, tractors have been adopted for land preparation by $83 \%$ of farmers in Myanmar and $96 \%$ of farmers in Bangladesh. However, sowing, weeding and harvesting in mungbean generally remain manual tasks [21]. Mechanical harvesting of mungbean (and of grain legumes more generally) is challenging for several reasons. First, unlike cereals, mungbean does not mature uniformly with the plant having ripe and unripe grain pods at the same time and continues to produce flowers and seed as long as water is supplied. Second, bean pods may shatter if overripe, letting the grain fall to the ground. Third, if it rains when seeds are ripe, then the grains may sprout, making them worthless. Some improved varieties have a more synchronized pod set, but this does not entirely solve these problems. Hand harvesting is a systemic response to the complex dynamics of the mungbean plant as it ripens. It maximizes the harvest while allowing flexibility. However, given that this process is labor-intensive, farmers and researchers are looking for alternatives. Some farmers have tried to modify combine harvesters for mungbean, but this is technically challenging. This is one of the challenges that the ACIAR project aims to address.

\subsubsection{Costs and Benefits from Mechanization for Smallholder Women}

Women smallholders do not necessarily benefit from mechanization of farm processes [32,33]. Within male-headed households (MHH), intra-household decision-making processes which favor male interests and labor time may result in less attention being paid to alleviating women's drudgery [32,34-36]. Female-headed households (FHH) may find it harder to adopt new machinery than $\mathrm{MHH}$ [33]. In Nepal, FHH were considerably less likely than $\mathrm{MHH}$ to adopt mini-tillers because $\mathrm{FHH}$ had not been targeted by the extension services [37]. However, in Vietnam, Chi [38] found that female-managed farms were more likely than male-managed farms to adopt rice harvesters and driers as these saved labor, reduced rice losses and improved product quality.

In other instances, mechanization is enabling women to take on men's roles [39]. Solar irrigation pumps installed in a village in Nepal experiencing high rates of male outmigration mean that women household heads can irrigate without relying on men [40]. Conversely, when women's tasks are mechanized, men may take over and accrue the financial benefits $[32,33]$. Nevertheless, women may accept tradeoffs between income and drudgery. In Zambia, men took over groundnut processing when mechanical shellers were introduced. This eliminated women's laborious work in handshelling [41]. In Vietnam, women smallholders were responsible for gap-filling and hand weeding in rice. The introduction of direct drum seeders eliminated this work, allowing smallholder women to spend more time with children and on income generation, including livestock, vegetables and petty trade. They also had more time for leisure, personal care and social activities [8]. In Bangladesh, the introduction of multi-crop reaper-harvesters meant that women smallholders no longer had to prepare food for hired laborers, which they associated with an increase in social status as well [18].

\subsubsection{Costs and Benefits from Mechanization for Hired Women Workers}

In Vietnam, the same drum seeders that benefited women smallholders resulted in catastrophic outcomes for hired laborers. It is estimated that $97 \%$ of landless women lost their jobs in gap-filling and hand weeding. Almost half of them (43\%) found it difficult to find alternative income-generating activities. Women's loss of income had significant negative consequences on family food security and health [8]. 
An analysis of Integrated Household Living Conditions Survey data (2005-2010) of women's participation in Myanmar's rapidly changing employment landscape showed that women increasingly gained employment in manufacturing [42]. However, their employment was negatively associated with household welfare. The authors speculate this may be due to a gender pay gap or the inability of households to substitute for women's work in household production.

In India, direct seeders, power weeders, harvesters and threshers are increasingly substituting for tasks predominantly performed by women. For instance, mechanized tilling, leading to reduced demand for women's skilled work in weeding, resulted in a $22 \%$ fall in women's agricultural labor in India between 1999 and 2011 [43]. Women are being pushed out of the paid agrarian economy on a massive scale but are, in general, not finding alternative paid work. This leads to a situation Pattnaik et al. [44] called the "feminization of agrarian distress."

Finally, a Malawian study found that the use of herbicides to reduce labor costs resulted in a significant loss of work opportunities-particularly for women, depressed rural wages and increased social differentiation [45]. While smallholders benefited, women hired workers and their families went hungry. This study highlights the potential hazards of neglecting the social equity implications of technology promotion and, as the authors state, begs the question as to whom agricultural research really expects to serve.

\section{Materials and Methods}

\subsection{Conceptual Approach}

We used a mixed-methods approach to provide a more complete picture of factors driving mechanization, its potential impacts and tradeoffs. To understand the economic motivation of farmers and the extent of the possible employment effects, we describe the results of a quantitative study and conduct an ex-ante partial budget analysis. Qualitative data provide information on the importance of other motivations for mechanization. To understand the potential impacts of mechanization on drudgery and employment among family members and hired laborers, we built upon estimates of labor demand. We combined this with insights from qualitative data to describe how these changes are likely to affect livelihoods.

\subsection{Quantitative Data}

Quantitative data were collected through a household survey among mungbean producers in Myanmar and Bangladesh. Data were collected from July 2018 to February 2020 using a stratified random sample from the major mungbean producing areas in Myanmar and Bangladesh. In Myanmar, we selected Magway and Sagaing Regions to represent the Central Dry Zone and Bago and Yangon Regions to represent Lower Myanmar. In Bangladesh, Natore and Pabna Districts were selected to represent the north and Jhenaidah District to represents the south. In each of these locations, the research team, using secondary data, identified three townships (in Myanmar) and four unions (in Bangladesh) where mungbean production is common. From each township/district, we then randomly selected 2-3 villages, which provided 125 sample observations per region/district. The total sample included 334 mungbean farmers from 40 villages in Bangladesh and 518 farmers from 44 villages in Myanmar (Table 1). In Myanmar, 24 farmers had already adopted combine harvesting in mungbean production and were therefore excluded in part of the analysis. As the sample size was not proportional to the total mungbean area per location, survey weights were used to estimate means at the national level. 
Table 1. Geographic distribution of the quantitative sample of mungbean farmers.

\begin{tabular}{cccc}
\hline Location & Unions/Townships & Villages & Households \\
\hline Myanmar (sum) & 13 & 44 & 518 \\
Bago & 3 & 9 & 142 \\
Magway & 5 & 13 & 130 \\
Sagaing & 3 & 12 & 131 \\
Yangon & 2 & 10 & 115 \\
Bangladesh (sum) & 14 & 40 & 334 \\
Jhenaidah & 8 & 14 & 137 \\
Natore & 3 & 17 & 134 \\
Pabna & 3 & 9 & 63 \\
Total & 27 & 84 & 852 \\
\hline
\end{tabular}

The person in the household mostly involved in mungbean production was selected as primary respondent. The survey collected data on production methods, crop yield, revenue and cost of each mungbean production cycle. It also collected detailed data on farm labor use in mungbean such as the number of days and hours spent on an activity by household members and hired workers, disaggregated by age category and gender. These data were converted to standard 8-h labor days in the analysis. We also collected data on the gross revenues and costs of all other crop, livestock and enterprises of the household. These data were used to estimate the household income. To measure perceptions about mechanized harvesting respondents were asked for their support of statements on the mungbean and rice harvests, using a five-point Likert scale. If the primary respondent was a man, the questions were also asked to the woman in the household who was most involved in the mungbean production. Finally, the survey captured basic household data such as family composition, age, education, asset ownership and income sources. We added questions on the rice harvest to understand the cost structure in its mechanized harvest. Where a combine was used, we also asked for an estimate of the hypothetical manual harvesting cost.

\subsection{Qualitative Data}

The qualitative research sites were purposively selected from the quantitative research sampling frame. Research activities were conducted separately with hired laborers and with smallholders (Table 2). These included sex-disaggregated focus group discussions (FGDs) on four different topics. All four were held with women and three were separately held with men. These were run by facilitators of the same gender. Additional activities included an activity with husband-wife couples, a community profile (mixed gender) and a mungbean value chain analysis (VCA) with additional key informant interviews (KIIs) (mixed gender). Tools were partly based on the GENNOVATE (gender, norms and innovation) research guide [24].

FGDs 3-5 were applied to both smallholders and hired laborers. FGD 3 asked a couple to reflect individually and then together on their visions for the future. Discussion focused on (gendered) factors hampering or facilitating vision realization. FGD 4 asked respondents to explore the respective abilities of women and men to respond to mechanization through innovating into new livelihoods. FGD 5 asked women to reflect on their sense of empowerment. For smallholders, FGDs 1 and 2 investigated the role of mungbean in the local agricultural system and specifically on their own farm. For hired laborers, FGDs 6 and 7 focused on how they earn a living and the relative significance of mungbean (across production to post-harvest processing) to their livelihoods. Across all FGDs, respondents were asked to reflect on who makes key decisions on the topics discussed. Forces driving system change, and their effects, were explored. To help understand gender norms, and if they are changing, all respondents in every FGD were asked to discuss what gender equality means to them and to provide local examples. 
Table 2. Qualitative research tools applied in Myanmar and Bangladesh, showing the average numbers of participants per tool.

\begin{tabular}{|c|c|c|c|c|c|}
\hline \multirow[b]{2}{*}{ Research Tool } & \multicolumn{2}{|c|}{ Smallholders } & \multicolumn{2}{|c|}{ Hired Laborers } & \multirow{2}{*}{$\begin{array}{c}\text { Community } \\
\text { Mixed Gender }\end{array}$} \\
\hline & Women & Men & Women & Men & \\
\hline \multicolumn{6}{|l|}{ Community Level Activities } \\
\hline Value chain study & & & & & $6-10$ \\
\hline Community profiles: 4 modules (KIIs) & & & & & $8-10$ \\
\hline \multicolumn{6}{|c|}{ Smallholder FGD } \\
\hline FGD 1: Mungbean system (i) & $6-8$ & $6-8$ & & & \\
\hline FGD 2: Mungbean system (ii) & $6-8$ & $6-8$ & & & \\
\hline Activity 3: Planning for the future (couple exercise) & 1 & 1 & & & \\
\hline FGD 4: Characteristics of innovators & $6-8$ & $6-8$ & & & \\
\hline FGD 5: Women's empowerment & $6-8$ & 0 & & & \\
\hline \multicolumn{6}{|c|}{ Hired Laborers FGD } \\
\hline FGD 6: Livelihood strategies & & & $6-8$ & $6-8$ & \\
\hline FGD 7: Work in mungbean & & & $6-8$ & $6-8$ & \\
\hline Activity 3: Planning for the future (couple exercise) & & & 1 & 1 & \\
\hline FGD 4: Characteristics of innovators & & & $6-8$ & $6-8$ & \\
\hline FGD 5: Women's empowerment & & & $6-8$ & 0 & \\
\hline Average numbers of participants per community & $25-33$ & $19-25$ & $25-33$ & $19-25$ & $14-20$ \\
\hline
\end{tabular}

Sampling criteria were as follows: 6-8 respondents per sex-disaggregated FGD. Smallholders had to grow mungbean over the past three years. Hired laborers needed to be landless women and men workers known to regularly participate in mungbean harvesting. Every respondent had to come from a different household, and they were drawn from different locations in each community. Respondents for the community profile (average eight per community, women and men) were expected to be of high standing in the community and to be able to contribute diverse knowledge: for instance, elected village leaders, healthcare staff and teachers. The value chain exercise was conducted more opportunistically, with respondents selected on the basis of their known participation in different locations in the mungbean value chain.

Village 1 is in Lower Myanmar. It had 917 households in 2019. Of these, 600 households (around two thirds) were landless and worked as hired laborers. Village 2 in the Central Dry Zone in Myanmar had 214 households in 2019. About one third $(30 \%=63$ households $)$ worked primarily as agricultural laborers. Village 3 in northern Bangladesh had around 785 households. Of these, 456 households provide hired labor (58\%). Village 4 in southern Bangladesh had 687 households in 2019 with 376 providing hired labor (54\%).

\subsection{Ex-Ante Partial Budget Analysis}

To calculate the likely impact of mechanized harvesting on farm incomes and labor demand, we combined the survey data on mungbean production with a set of assumptions. These were partially based on the experience of mechanization in the rice harvest, which provides a local example of the mechanized harvesting of a field crop. Since mungbean is usually harvested in one to three (but occasionally as many as five) hand-pickings, farmers adopting machine harvesting may opt to conduct one or two pickings by hand before using a combine harvester for the last picking. This decision represents a tradeoff for farmers: an increased number of harvests raises labor costs but also yields, since more pods are allowed to ripen, thus reducing losses. We assessed this tradeoff using a scenario approach assuming one, two or no hand picking and one machine harvest. For simplicity, we ignored effects mediated through changes in the growing period, the speed of the harvest, prices or the area planted. We calculated the hypothetical production cost, yield and profit for each season and aggregated the results to a single observation per household. 
We then assessed the effect of mechanization on yield by estimating a model with crop yield as dependent variable and the number of pickings as independent variable while controlling for other influencing factors. These include region effects, planted area, length of the growing period (i.e., the time from planting to the last harvest), fertilizer expenditures and pesticide expenditures. We included squared terms for all continuous variables to allow for non-linear relations. The number of harvests was entered as a set of dummies for which we estimated semi-elasticities, which were used as proportional yield reductions under the three scenarios. We used the same controls to estimate the effect of a reduction in harvesting frequency on the share of the total yield harvested in the mechanized harvest, compared to possible earlier hand pickings. This was done separately for households that harvest at least two and three times. We assumed that $10 \%$ of the value of the mungbean share harvested mechanically is lost due to seed losses, grain breakage and other effects of combine harvesting. Hence, we estimated the value of mungbean as:

$$
Y^{S}=\left\{\begin{array}{c}
\left(Y^{M} *\left(1-P_{H}^{S}\right) *\left(1-L * C_{S}\right), H>S\right. \\
Y^{M} *\left(1-L * C_{S}\right), H \leq S
\end{array}\right.
$$

where $Y^{S}$ is the yield in scenario $S, Y^{M}$ is the observed yield, $P_{h}^{S}$ is the yield penalty for reducing harvest frequency from $h$ to $S, L$ is the yield penalty for seed losses and breakages and $C_{S}$ is the share of the yield produced in the mechanized harvest.

Our assumptions on labor reductions and rental cost of combine harvesters were based on the use of combines in the monsoon rice harvest in Myanmar. First, we considered that a reduced number of harvests affects the total labor requirement, even without mechanization. We based the size of this effect on a regression of the total labor requirement on the harvesting frequency and controls. To account for the non-normal distribution of the variables, we used a log-log specification. As controls, we added the planted area, yield, the length of the crop cycle and seasonal and regional effects. Based on a comparison of the model fit, only the planted area was also entered as squared term. We transformed the resulting coefficient into estimates of the relative impact. Second, we assumed that the labor hours of each person group participating in the harvest are equally divided over the number of harvests. Third, the labor reduction in the mechanized harvest was calculated as the relative change in the average quantity of labor required by farmers who use a combine harvester in the rice harvest, compared to what they estimated to have required for a hand harvest. This was done separately for men and women of the farming family and hired men and women. We combine the assumptions on the labor-saving effects by calculating

$$
L_{g}^{S}=\left\{\begin{array}{c}
L_{g}^{M} * F_{H}^{S} *\left(1-\frac{R_{g}}{S}\right), H>S \\
L_{g}^{M} *\left(1-\frac{R_{g}}{H}\right), H \leq S,
\end{array}\right.
$$

where $L_{g}^{S}$ is the time group $\mathrm{g}$ works in the mungbean harvest if harvest number $S$ is mechanized. $L_{g}^{M}$ is the labor currently required, $F_{H}^{S}$ is the estimated reduction due to a reduction from $\mathrm{H}$ to $\mathrm{S}$ harvests and $R_{g}$ is the ratio of labor remaining for group $\mathrm{g}$ in the mechanized rice harvest. We assumed that labor cost, including in-kind provisions, increase at the same rate as the labor hours. Besides changes in the labor cost, we assumed that the production cost increases by the average rental cost for a combine harvester in the rice harvest. As we can only observe mechanization in the rice harvest in Myanmar, we assumed that relative effects on labor and the absolute rental cost of the combine is the same in both countries and that they rise proportionally with the planted area. With mechanization likely to require the application of an herbicide or plant growth regulator for desiccation, we added the average cost of an herbicide application observed in our sample of mungbean farmers. 


\section{Results}

\subsection{Description of Mungbean Production}

Our data show that in our sample mungbean farming households in Bangladesh and Myanmar are on average home to about four household members. One percent of surveyed farms in Bangladesh and 9\% of farms in Myanmar are headed by a woman and the share of households where a woman is responsible for mungbean production is only $1 \%$ higher in each country (Table 3). Farmer respondents in Bangladesh own on average 0.65 ha of land and plant mungbean in a single season on 0.18 ha. Farmer respondents in Myanmar own an average $5.43 \mathrm{ha}$, grow mungbean on average in 1.1 seasons and plant a total of 3.14 ha. This equates to around 17 times more land devoted to mungbean per household than in Bangladesh. In both countries, the crop stays about 80 days in the field and yields just above $0.9 \mathrm{t} / \mathrm{ha}$. This equates to a financial value of about $650 \mathrm{USD} / \mathrm{ha}$. Farmers in Bangladesh keep a larger share to consume, share and save as seed (ca. $90 \mathrm{~kg} / \mathrm{ha}$ from the total). Farmers in Myanmar kept a smaller quantity (ca. $40 \mathrm{~kg} / \mathrm{ha}$ from the total), which corresponds approximately to the seed rate required to replant the area.

Table 3. Sample characteristics of mungbean producing households in Bangladesh and Myanmar, 2019.

\begin{tabular}{|c|c|c|c|c|}
\hline & \multicolumn{2}{|c|}{$\begin{array}{c}\text { Bangladesh } \\
\quad(n=334)\end{array}$} & \multicolumn{2}{|c|}{$\begin{array}{c}\text { Myanmar } \\
(n=518)\end{array}$} \\
\hline & Mean & SD & Mean & SD \\
\hline \multicolumn{5}{|l|}{ General characteristics: } \\
\hline Land owned (ha) & 0.65 & 0.71 & 5.43 & 6.41 \\
\hline Female headed household (proportion) & 0.01 & 0.10 & 0.09 & 0.29 \\
\hline \multicolumn{5}{|l|}{ Mungbean production: } \\
\hline Woman responsible for mungbean (proportion) & 0.02 & 0.15 & 0.10 & 0.30 \\
\hline Area planted (ha) & 0.18 & 0.14 & 3.14 & 5.44 \\
\hline Crop yield (t/ha) & 0.93 & 0.57 & 0.91 & 0.52 \\
\hline Sold (t/ha) & 0.82 & 0.55 & 0.87 & 0.51 \\
\hline Consumed, shared, saved as seed ( $t / h a)$ & 0.09 & 0.10 & 0.04 & 0.04 \\
\hline Production value (USD/ha) & 659.09 & 415.37 & 647.37 & 526.72 \\
\hline Production cost (USD/ha) & 364.14 & 386.70 & 432.03 & 234.65 \\
\hline Labor cost, total (USD/ha) & 167.41 & 163.74 & 186.30 & 133.07 \\
\hline Labor cost, hired women harvest (USD/ha) & 115.06 & 138.91 & 114.40 & 105.63 \\
\hline Labor cost, hired men harvest (USD/ha) & 8.94 & 41.30 & 16.34 & 22.29 \\
\hline Profit (USD/ha) & 294.95 & 494.32 & 215.34 & 496.46 \\
\hline Profit (USD/household) & 58 & 111 & 1019 & 3382 \\
\hline Mechanized land preparation (proportion) & 1.00 & 0.05 & 0.85 & 0.36 \\
\hline Mechanized harvesting (proportion) & 0.00 & 0.00 & 0.05 & 0.21 \\
\hline
\end{tabular}

Note: SD. Standard deviation.

Production costs per hectare were significantly higher in Myanmar than in Bangladesh (432 compared to 364 USD/ha), though neither the difference in input cost nor in labor cost is significant on its own. Labor costs contribute more than $40 \%$ of the total production cost in both countries. About two thirds of this cost are wages to women hired for harvesting (115 USD/ha in Bangladesh, 114 USD/ha in Myanmar). Men are much less commonly employed in the harvest, with expenditures on men workers being 9 USD/ha in Bangladesh and 16 USD/ha in Myanmar. The average wages per 8-h labor-day are similar for men and women. Overall, though, wage costs are considerably higher in Myanmar (4.36 USD per hired woman and 4.51 USD per hired man) than in Bangladesh (3.64 USD per hired woman and 3.65 USD per hired man).

Profits from mungbean production average around 215 USD/ha in Myanmar and 295 USD/ha in Bangladesh. Due to the large variation within both countries, this difference is not statistically significant. However, as the area planted to mungbean per farm is about 17 times smaller in Bangladesh than in Myanmar, the average mungbean producing 
households in Bangladesh earned on average 58 USD from mungbean, compared to 1019 USD in Myanmar.

Mechanized land preparation was adopted by all mungbean farmers in Bangladesh and $85 \%$ in Myanmar. While no farmer in Bangladesh used machinery to harvest the crop, $5 \%$ of the farmers in Myanmar had started using a modified combine harvester in the mungbean harvest.

In Bangladesh, the production of 1 ha of mungbean took on average about 82 standardized 8-h labor-days from family members, hired laborers and to a smaller degree children and workers without monetary pay. In Myanmar, production of 1 ha required an average of 52 labor-days (Table 4).

Table 4. Labor use in mungbean production and harvesting in Bangladesh and Myanmar, in standard 8-h working days per hectare, 2019.

\begin{tabular}{|c|c|c|c|c|}
\hline & \multicolumn{2}{|c|}{$\begin{array}{c}\text { Bangladesh } \\
(n=334)\end{array}$} & \multicolumn{2}{|c|}{$\begin{array}{l}\text { Myanmar } \\
(n=494)\end{array}$} \\
\hline & Mean & SD & Mean & SD \\
\hline \multicolumn{5}{|l|}{ Entire production } \\
\hline All labor, women & 52.18 & 44.73 & 37.85 & 31.52 \\
\hline All labor, men & 30.09 & 28.09 & 14.44 & 9.62 \\
\hline \multicolumn{5}{|l|}{ Harvesting stage: } \\
\hline Own household labor, women & 4.45 & 14.09 & 1.35 & 2.75 \\
\hline Own household labor, men & 4.10 & 10.85 & 1.09 & 2.50 \\
\hline Hired labor, women & 33.67 & 37.51 & 27.46 & 23.91 \\
\hline Hired labor, men & 2.54 & 11.99 & 3.87 & 5.20 \\
\hline Non-hired outside labor, women & 0.18 & 2.23 & 0.13 & 2.32 \\
\hline Non-hired outside labor, men & 0.20 & 3.65 & 0.00 & 0.10 \\
\hline
\end{tabular}

Note: SD, Standard deviation. The sample excludes 24 farmers in Myanmar who used a combine to harvest mungbean.

In Bangladesh, hired women provided about 34 labor days per hectare $(75 \%$ of all labor required for the harvest). In Myanmar, hired women provided about 27 labor days per hectare $(81 \%)$ to the harvest. Hired men provided three and four days per hectare, respectively. Smallholder family members of both genders provided four labor days per hectare to the harvest in Bangladesh and one day per hectare in Myanmar. The differences in the average area planted by each farm mean that differences in the per-hectare statistics do not reflect the differences in the workload per household. Regardless of the total land area planted to mungbean, family men and women spend less than one day harvesting mungbean in Bangladesh and just over three days in Myanmar. It is not clear whether this work involved actually picking alongside hired laborers or supervising this work.

\subsection{Drivers of Mechanization in the Mungbean Harvest}

\subsubsection{Partial Budget Analysis of Mechanized Mungbean Harvesting}

First, our ex-ante partial budget analysis relies on the experience of labor substitution in the rice harvest. Our data show that, while $93 \%$ of mungbean farmers in Bangladesh grew rice, none of them used a (mini-)combine in the rice harvest. In Myanmar, 73\% of mungbean farmers had grown rice over the previous year, mostly planted during the monsoon season. Of these farmers, $64 \%$ used a combine to harvest the monsoon rice, paying an average 81 USD per hectare for this service. Comparing the labor requirements with the combine harvester with farmer estimates of labor demands prior to mechanization shows a reduction in the employment of hired women by $98 \%$ and that of hired men by $83 \%$. Farm household labor reduced by $51 \%$ for women and $70 \%$ for men. We assume that the same reductions would apply for mechanized harvests of mungbean, excluding previous hand pickings.

Second, the regression results suggest that a reduction in the number of harvests is associated with a reduction in the required labor, irrespective of mechanization. The labor 
required for production increases significantly with harvesting frequency (Table A1 in Appendix A). Compared to a single harvest, adding a second harvest is associated with a $41 \%$ increase in labor hours. Switching from one to three harvests is associated with a $113 \%$ increase and switching from one to four harvests with a $160 \%$ increase.

Third, we assume that reductions in harvest frequency due to mechanization would significantly reduce crop yield. Our regressions show that in the current manual harvesting system a shift from one to two hand-harvests is associated with an $18 \%$ yield increase. A move to three harvests is associated with a 38\% yield increase (Table A2 in Appendix A). Furthermore, in the current system of hand-harvesting, a reduction in the frequency of harvests to two harvests is associated with a significantly higher share of the yield being produced in the second harvest (Table A3 in Appendix A). This implies higher seed losses if the second harvest is mechanized.

Based on the model assumptions and the associations found in our data, Table 5 shows the potential effect of the three different mechanization scenarios. Due to the fixed costs of machine rental and desiccant application, the substitution of labor does not result in a strong reduction of production cost. Under full mechanization, the total production cost drops by $10-11 \%$ and with one previous hand picking they remain at the current level. A combination of mechanization with two hand pickings results in an increase in production costs.

Table 5. Estimated effects of mechanization at the farm level.

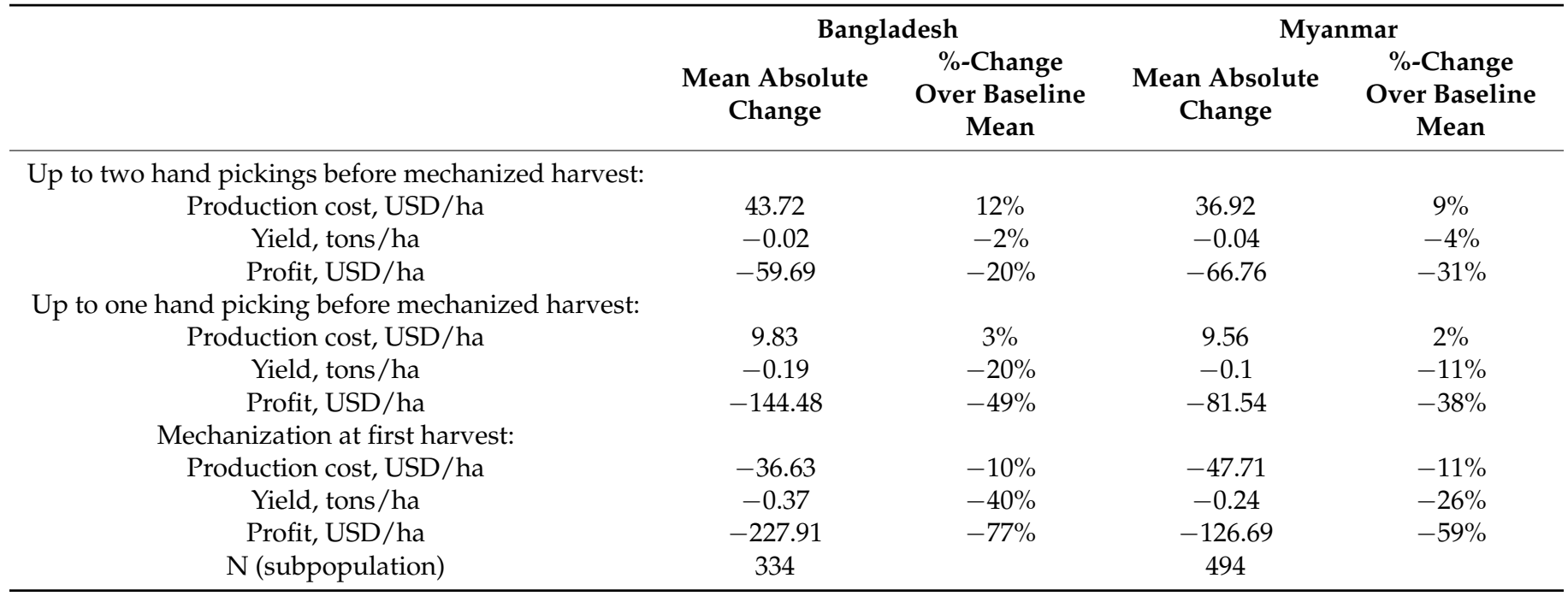

If switching to full mechanization, then yield losses would be $40 \%$ in Bangladesh and $26 \%$ in Myanmar. Full mechanization would therefore cause a reduction of average profits by $77 \%$ in Bangladesh and 59\% in Myanmar. However, a harvesting regime that allows for up to two hand pickings would result in reductions by $20 \%$ in Bangladesh and $31 \%$ in Myanmar.

Due to variation between farmers, we estimate that $9 \%$ of farmers in Bangladesh and $11 \%$ of farmers in Myanmar would currently be able to increase their profits from mungbean by adopting full mechanization of their harvest. These numbers depend strongly on local wage rates. Assuming a higher labor cost while keeping all other variables stable shows that a rise in wage rates could quickly increase the share of farmers for which mechanization is profitable. If the cost of labor was to be $100 \%$ over current rates, $31 \%$ of farmers in Bangladesh and $43 \%$ of farmers in Myanmar would find mechanization profitable. At a $300 \%$ increase (the approximate increase after 30 years with 5\% annual wage growth), $55 \%$ of farmers in Bangladesh and $80 \%$ of farmers in Myanmar would increase profits with mechanization. At all variations of the labor cost, full mechanization is profitable for a 
larger share of farmers in Myanmar than combinations with hand picking. In Bangladesh, the combination with two hand pickings is profitable for the largest proportion of farmers.

\subsubsection{Other Economic Motivations for the Adoption of Mechanized Harvesting}

Our partial budget analysis suggests that mechanized mungbean harvesting is currently only profitable for a small share of farmers. However, this analysis only captures effects on the average income. The qualitative data show that the most important reasons farmers in Myanmar and Bangladesh gave for wanting to mechanize mungbean harvesting were ensuring timeliness through avoiding the risk of rainy weather and saving labor costs. In Village 1 in Myanmar, a few mungbean fields were harvested mechanically in 2018. During the same period, catastrophic floods were experienced which ruined the mungbean harvest for most other farmers.

In 2019, rain appeared to threaten the harvest again, leading to strong demand for combine harvesters as farmers panicked. As a consequence, many mungbean fields on flat land with large fields suitable for machinery (about two thirds of village lands) were harvested mechanically. One woman farmer with 3.24 ha of mungbean explained her reasoning, "The cost difference between combine and manual labor for harvesting is 15,000 to 25,000 kyat per acre. But the cost is not the only issue. Timeliness is improved as combine harvesting only takes one day. Rain can ruin the entire crop, and climate change is making things more uncertain" (Village 1, smallholder woman, Myanmar).

In Bangladesh, no farmers had experienced mechanical harvesting of mungbean and could not envisage it due to their experience of hand-harvesting over several weeks. However, they generally agreed that, were the machinery to work, "We want it, it is urgent. We want it because harvesting will be less laborious and less costly. Also, it will save our valuable time. During bad weather, it will save mungbean from damage in the field" (Village 3, smallholder man, Bangladesh). Revealingly, this logic is almost precisely the same as that expressed by the woman farmer in Myanmar.

Although most farmers in Village 1 in Myanmar hired combines to harvest their mungbean in 2019, they were disappointed with the product. This is because combine harvesters had been adapted locally with little knowledge of precisely which adaptions needed to be made. Losses were high and the grain quality was poor, leading to low sales prices. Men reported, "We experienced disadvantages using machinery and just used it to avoid poor weather conditions. If the weather is good we just want to use manual labor. Otherwise, if all the current disadvantages are overcome through a new machine we want to use machinery for all operations" (Village 1, smallholder man, Myanmar).

\subsubsection{Non-Economic Motivations for the Adoption of Mechanized Harvesting}

Although the quantitative survey shows that smallholder women and men do not devote much time to harvesting mungbean, this finding might not fully reflect the relative significance of the task in the agricultural year according to other criteria, for instance labor intensity and difficulty. In Bangladesh, men and women farmers equally (89\%) supported the statement that mungbean harvesting is amongst the most arduous types of work on the farm. In Myanmar, just over half of women and men farmers considered mungbean harvesting to be arduous while $36 \%$ of women and $38 \%$ of men agreed with the statement that it takes little effort. Agreement with statements may depend on whether the respondent themselves engage in harvesting or supervise others in this task. In both countries, respondents agreed that hand-harvesting demands a lot of women's time (79\% of men and women in Myanmar and $85 \%$ of men and $87 \%$ of women in Bangladesh) as well as men's time (66\% among men in Myanmar and 79\% among men in Bangladesh).

Perceptions about the benefits of time-saving benefits of mechanization are supported by respondent agreement with statements on the benefits of the already mechanized rice harvest in Myanmar. Just under $90 \%$ of men and women farmers supported statements that the introduction of combine harvesters saves men and women a lot of time. The statement that the mechanization is good for the entire family was supported by $69 \%$ of women and 
$73 \%$ of men. Nevertheless, about one third of men and women preferred hand-harvesting in rice.

The qualitative data accord with the quantitative data in showing that smallholder women in both countries highlight time savings. "Mechanization will save us time and field work will be easy. It will reduce the time spent on harvesting" (Village 3, smallholder woman, Bangladesh). In Village 4, almost no women were hired for mungbean harvesting meaning that the entire workload fell on smallholder women themselves.

Smallholder women highlighted burdens associated with hired laborers which mechanization would eliminate. For example, women in Myanmar prepared food for hired laborers (this is common practice in some parts of Bangladesh but not in our two study communities). While the quantitative survey of this study tried to capture it, the economic costs in terms of food bought or taken from the farm is rarely calculated in cost-benefit analyses, nor are the time costs to women. One woman smallholder in Myanmar explained that prior to mechanized harvesting of mungbean, "Our temporary hired workers came from Bago West. We regularly employed 30 to 50 laborers for the mungbean harvest (across 18 acres). We provided them a simple temporary place made of bamboo to sleep. It is hard to manage so many people. I have to get up at 4 am to cook rice-and pay someone to help me-in a huge pot. Then the same work for lunch and supper. We give them fish each day and meat once a week (chicken or pork). We add a few vegetables from our home garden" (Village 1, woman smallholder, Myanmar).

It is not surprising that women smallholders highlighted time savings because they, rather than men, work in the fields on harvesting mungbean and providing for hired workers. In Myanmar, though, men smallholders also commented on time savings, saying "We will get more time to spend with our family", and "We can do more social and community works" (Village 1, smallholder man, Myanmar). These comments highlight an important aspect of many discussions held with respondents in Myanmar, namely the ability of individuals to contribute to community well-being, including through maintaining Buddhist temples, repairing roads and community cooking at events (which is a male task). Such deeds help to accumulate merit (important in Buddhist religion) as well as contribute to village development and social capital.

\subsection{Reduction of Labor Incomes in Mechanized Harvesting}

Production cost reductions attributable to mechanization lead to reduced demand for hired labor. Combining national agricultural statistics on the planted mungbean area with our data on the average rate of employment per hectare of mungbean shows that the mungbean harvest creates about 34.06 million days of employment for hired women in Myanmar and 1.39 million days employment for hired women in Bangladesh. This corresponds to wages of 141.91 million USD in Myanmar and 4.75 million USD in Bangladesh $[46,47]$. Assuming the production area remains stable, full mechanization of the mungbean harvest implies the almost complete disappearance of this source of employment for hired women (Table 6). For hired men, just 11-14\% of employment would remain. If we allow for two hand pickings prior to mechanizing the final harvest, the reductions in labor requirements are smaller, at $34 \%$ for women and $28 \%$ for men. Therefore, compared to full mechanization, the average results suggest that combining mechanization with two hand pickings would result in a smaller reduction of incomes for farmers and workers alike. As farm profits derived from mungbean are not expected to increase in our model, farmers are unlikely to increase the land area devoted to mungbean production. This could otherwise have compensated for a part of the employment loss.

The views of the male and female farm household members in the quantitative survey support the finding that the mechanization of the mungbean harvest would lead to the removal of women from harvesting, with detrimental effects for hired laborers. In Bangladesh, $70 \%$ of men and women agreed that the problem about mechanization is that it reduces work and income for landless people. In Myanmar, 50\% of women and $59 \%$ of men agreed. The statement that mechanization would exclude women from employment in hand-harvesting was supported by $63 \%$ of men in Bangladesh and $65 \%$ 
of men in Myanmar. Among women, it was supported by $60 \%$ and $54 \%$, respectively. Only $34 \%$ of women in Bangladesh and 21\% of women in Myanmar agreed with the statement that women can operate farm machinery equally well as men. The support was $2 \%$ and $3 \%$ lower among men, respectively.

Table 6. Estimated wage reduction with mechanization.

\begin{tabular}{|c|c|c|c|c|}
\hline & \multicolumn{2}{|c|}{ Bangladesh } & \multicolumn{2}{|c|}{ Myanmar } \\
\hline & $\begin{array}{c}\text { Mean Absolute } \\
\text { Change }\end{array}$ & $\begin{array}{c}\text { \%-Change } \\
\text { Over Baseline } \\
\text { Mean }\end{array}$ & $\begin{array}{c}\text { Mean Absolute } \\
\text { Change }\end{array}$ & $\begin{array}{c}\text { \%-Change } \\
\text { Over Baseline } \\
\text { Mean }\end{array}$ \\
\hline \multicolumn{5}{|c|}{ Up to two hand pickings before mechanized harvest: } \\
\hline Wages for hired women, USD/ha & -39.48 & $-34 \%$ & -38.42 & $-34 \%$ \\
\hline Wages for hired men, USD/ha & -2.49 & $-28 \%$ & -4.57 & $-28 \%$ \\
\hline \multicolumn{5}{|c|}{ Up to one hand picking before mechanized harvest: } \\
\hline Wages for hired women, USD/ha & -71.02 & $-62 \%$ & -62.99 & $-55 \%$ \\
\hline Wages for hired men, USD/ha & -4.84 & $-54 \%$ & -7.36 & $-45 \%$ \\
\hline \multicolumn{5}{|l|}{ Mechanization at first harvest: } \\
\hline Wages for hired women, USD/ha & -114.33 & $-99 \%$ & -113.52 & $-99 \%$ \\
\hline Wages for hired men, USD/ha & -7.99 & $-89 \%$ & -14.11 & $-86 \%$ \\
\hline $\mathrm{N}$ (subpopulation) & 334 & & 494 & \\
\hline
\end{tabular}

In Myanmar, where mechanization of the rice harvest is common, similar judgements were made. Half of men and women supported a statement that mechanization is bad for the poor and landless; $54 \%$ of women and 59\% of men agreed that the role of women in the rice harvest was reduced with the adoption of combine harvesters.

Significance of Employment in the Mungbean Harvest for Hired Laborers

Women in both countries dominate harvesting - in Myanmar, the ratio of hired women to men in Villages 1 and 2 is 4:1. In Bangladesh, the employment of men is negligible in Villages 3 and 4 . A closer look at which women work in mungbean shows that married women with children are the most likely to do so. This is because they are the least mobile and have the fewest alternative income-generating options. Gender norms in both countries mean that married women are expected to take care of children, other family members and livestock and maintain the household in general, leaving little time for paid work. Conversely, men hired laborers are more likely to find local work, and they are usually able to travel to other destinations to find work. Some women in Myanmar pointed out that gender norms keep the entire household poor and lock them into poverty because men are not necessarily able to adequately provide for the whole family on their own. Poor men experience low bargaining power and typically have to take on arduous low paid work. Women considered that this lack of gender norm flexibility means children are taken out of school, and necessary repairs to the home are not made. More broadly, women as well as men in Myanmar universally agreed that women's income is important to supporting the household. The issue is rather the degree of compromise which can be made between this objective and obeying gender norms.

Women in Village 1 in Myanmar earn 50-100\% of their annual agricultural income from mungbean. Of this, 20-28\% is from harvesting and post-harvest processing; the remainder is from land preparation and tending mungbean during the growing season. This money is spent on food, clothes, school fees, livestock inputs, social occasions, health and more and is seen by both women and men as important to family welfare. Mechanizing mungbean harvesting will, therefore, eliminate around one fifth to one quarter of women's annual income. There are almost no other opportunities for women to generate off-farm livelihoods in Village 1 since all potential ideas (e.g., grocery, livestock, tutoring and tailoring) have long been realized, and, since this is a poor community, sales opportunities are limited. Hired women who have lost work harvesting mungbean explained that they are now foraging for wild food, including diving for snails. 
Village 2 in Myanmar is different. It benefits from being close to a vibrant town as well as a home-cottage-based rope-making industry. Many women take advantage of these opportunities, but again married women with small children find their options restricted and therefore mungbean harvesting remains an important source of income for them. Overall, however, the implications of mechanically harvesting mungbean are likely to be less serious with women experiencing around 10\% loss in income.

However, mungbean harvesting is the only paid fieldwork option open to women in Village 3 in Bangladesh. Men explained that "Women only work in the month of May. Their male partners do not allow them to work in other months" (Village 3, hired labor men, Bangladesh). In Village 4, mungbean is the most important crop to women laborers though a few work as maid-servants, in chili and vegetables and in making fish traps for sale. Interestingly, men in Village 4 did not discuss this other work and claimed that women only pick mungbean. In Village 4 particularly, men reiterated the importance of women having sufficient time for household tasks and childcare as a reason for not overburdening them with fieldwork, and, in both Villages 3 and 4, men cited restrictive social norms which limit women's mobility and work beyond the home. Even so, when women in Village 4 were asked about what they would do if mungbean harvesting were mechanized, they thought they could rely on making fish traps, work as maid-servants and other forms of minor income generation. Interestingly, they saw an opportunity. "We want to adopt mechanization. We have to learn how to operate machinery. We will learn from each other then we will operate it. We want to get training from agricultural research organization" (Village 4, hired woman, Bangladesh).

Is such a seemingly radical idea possible? Discussions around gender equality and social norms showed that considerable change has been experienced over just a few years in Villages 3 and 4 in Bangladesh in many areas of life. Most-but not all-men respondents openly espoused gender equality and said they practiced it in their daily lives, for example, through sharing food equally, ensuring everyone is well-clothed and through listening carefully to women's views in intra-household decision-making. In these communities, gender norm change is reflected in high rates of girls being schooled and the presence of women teachers. One of the most visible changes is women moving into fieldwork, with mungbean being the most important example of this in the two villages studied. Paid fieldwork in mungbean for women began around a decade ago. Smallholder farms began to find it difficult to cover labor requirements due to extraordinary increases in productivity. This is attributable to the use of improved varieties and technologies and ever-expanding markets both locally and further afield (Community Profile, Villages 3 and 4, Bangladesh). Although social norms initially hampered acceptance of women working in the fields, today "Society honors women who work as hired agricultural labor. They respect us. They know we are working for the family. If you can give a contribution it raises your prestige. People look at you in a different way", explained one woman (Village 3, hired worker woman, Bangladesh). Such women also experience more political voice in the community, being able to take their issues to the village council and expecting to be listened to. The money earned from mungbean harvesting is used to meet a variety of needs, with the most important being children's education. This is particularly important for boys who do not receive a government stipend (unlike girls). One woman said, "My children are my dream and my life. I invest my income and my life in both of them. I pray they won't be like me. They'll create a position for themselves in society" (Village 3, hired worker woman, Bangladesh).

Personal visions created by landless participants in Myanmar focused not only on their personal and family hopes for the future, but also poignantly (given their poverty) highlighted their longing to provide benefits to the whole community: a bridge, donation to a feeding center for poor children, a clinic and a pagoda. However, it is almost impossible for hired laborers to provide these benefits. Women explained "We try hard to contribute to the wellbeing of the community, but we have little time and leisure to relax. We only have an average of 15 days income per month and the other days we are always busy in mind trying to find work and money" (Village 1, hired worker woman, Myanmar). In Bangladesh, men laborers 
in Village 3 said they tried to contribute by helping to repair roads and building mosques. Women laborers in Village 4 described contributing towards religious programs.

\section{Discussion}

First, we hypothesized that mechanization of the mungbean harvest would reduce labor costs and thereby increases smallholder farm income. Second, we hypothesized that mechanized harvesting removes a source of drudgery from men and women in the farm household. Third, we hypothesized that mechanization eliminates an important income stream for hired women and men laborers. We expected that these hypotheses would allow us to consider potential gender tradeoffs between smallholder farm income, smallholder farmer well-being and hired labor well-being should mechanization occur.

Contrary to our first hypothesis, the ex-ante partial budget analysis suggests that reduction in the cost of labor is currently not a major motivation for mechanization. This is due to the relation between the assumed cost of mechanized harvesting and hand harvesting, as well as due to the substantial yield losses associated with the reduction of harvests. However, this may well change over time. Rising labor costs, the likelihood of reduced costs of mechanized harvesting and the introduction of new mungbean varieties with synchronous maturity is expected to improve the profitability of mechanization. Increases in average profits are also not the only motivation for farmers to adopt mechanization, as we showed that farmers in both countries are primarily motivated by the need to reduce their exposure to imminent weather risk: to ensure timely harvesting in the face of rain or flood. The labor intensity of mungbean harvesting means it can be difficult for all farmers to secure enough labor at the same time. Women smallholders outlined further benefits of mechanization; in particular, they need to prepare food for the hired workers, which consumes time and money.

Our second hypothesis is that hand-harvesting mungbean is perceived as an arduous and time intensive task. Mechanization is thus expected to reduce levels of effort. This is verified. Despite the relatively small involvement of family members in hand-harvesting mungbean, the reduction in drudgery provides smallholder farm families with an additional motive for mechanization. Women and men highlighted other important benefits. In Myanmar, these related specifically to the ability of the respondents as individuals to contribute to the well-being of the community through performing good deeds. Such actions can strengthen personal social capital and build community social cohesion. Merit making is important within Buddhist cosmology—it builds a ritual economy of merit based on spiritual rewards for material donations [48]. In the context of Myanmar, Dove [49] argued that giving trends in Myanmar (the highest in the world) are also a response to low government investment in basic social services and high levels of deprivation.

Finally, the results support the third hypothesis that mechanizing the mungbean harvest could remove vital income from the particularly vulnerable group of hired landless women. The qualitative data show that mungbean harvesting offers women, particularly married women, a very large percentage of their income. Women use this income to meet immediate household needs and invest it in their children's education, thus providing intergenerational benefits. In Bangladesh particularly, women noted that earning an income, modest though it may be, has elevated their standing at community level and enabled them to be seen and heard in community level forums. In Myanmar, women workers already find it difficult to accrue merit through giving, and this challenge is likely to deepen should they lose work through mechanization of mungbean harvesting.

\section{Conclusions}

Our study supports earlier studies that mechanization-especially when it targets "women's work" - is likely to benefit women smallholders but marginalize women hired workers. Since our study is primarily ex ante, the ways in which smallholder women may use their additional time, or whether hired laborers will in fact be able to find other work, 
is in reality unknown. However, overall, the prospects seem troubling for hired women and their families, and there may be intergenerational costs.

Is it possible to combine mechanization with handpicking? This could allow a win-win situation which is attentive to the social equity implications of new technologies highlighted by Bouwman, Andersson and Giller [45] above. Our results show higher average profits when the mechanized harvest is combined with prior hand pickings. Other production systems exhibited such models. For instance, during the transition to mechanized cotton harvesting in the Texas High Plains, farmers utilized mechanical stripping to harvest the crop remaining after previous hand pickings [50]. While the exact mechanics differ, there are parallels in the influence of the labor supply, weather risks, product quality and the publicly funded development of new agronomic methods and crop varieties that supported the advance of mechanization. These parallels suggest a need for more research into this and similar historic processes of mechanization. These insights could help to define policies and research that support a successive adoption of mechanized harvesting that reconciles the profitability of the production process with the preservation of workers' livelihoods.

A second way forward is to consider development approaches which shift gender norms to allow women and men to be more agentic in their responses. Women in particular are hobbled by norms which restrict their options. Our study shows that mechanizing mungbean harvesting will catalyze and cascade benefits and harms differentially to women hired workers and women smallholders. These benefits and harms have the potential to be intergenerational in nature and thus affect equitable achievement of the Sustainable Development Goals and the ambition to Leave No One Behind. More equitable gender norms will open up new opportunities for smallholder women as well as hired women through strengthening their agency, and it can be expected that wider benefits will accrue, including a reduction in poverty. Tackling gender norms requires a commitment to transformation, dedication and ambition, and it also requires significant cultural sensitivity. Experience has accumulated on working with men's organizations for change, on household methodologies, organizational change strategies and other approaches. The best of these are often developed by national actors in partnership with international players [51-55].

Mechanization is inevitable. Therefore, a third opportunity is to target women for training in managing and hiring out machinery. In Bangladesh, some women smallholders are co-managing hiring services with their husbands [18]. These women advertise mechanical reapers to other farmers through their social networks and provide various services. Some wives assist with accounting and keeping track of prospective clients [18]. Another study in northern Bangladesh showed that indigenous (Adivasi) Santal women, who had previously been excluded from agricultural training, took control of a woman's organization and used it to demand technical training for themselves and low-income Muslim women [56]. A third Bangladeshi study highlights the Samriddhi project. This trained very poor women and men to become Local Service Providers working through Service Provider Associations to provide, or to link, farmers with farm inputs, markets and finance [57].

Author Contributions: Conceptualization, L.D., C.R.F., P.S., T.M. (Thuzar Myint), A.M.S., T.M. (Theingi Myint) and R.M.N.; methodology, L.D., C.R.F. and P.S.; formal analysis, L.D. and C.R.F.; investigation, L.D., C.R.F., T.M. (Thuzar Myint), M.M.I., N.D.K., T.M. (Theingi Myint), A.M.S. and R.J.; writing-original draft preparation, L.D., C.R.F. and P.S.; writing-review and editing, M.M.I., N.D.K., T.M. (Theingi Myint), R.J. and R.M.N.; project administration, P.S. and R.M.N.; and funding acquisition, R.M.N. All authors have read and agreed to the published version of the manuscript.

Funding: Funding for this research was provided by the Australian Center for International Agricultural Research (ACIAR) under the project "Improved Mungbean Harvesting and Seed Production Systems for Bangladesh, Myanmar and Pakistan" and other long-term strategic donors to the World Vegetable Center: Taiwan, UK aid from the UK government, United States Agency for International Development (USAID), Germany, Thailand, Philippines, Korea and Japan. 
Institutional Review Board Statement: The study was exempted from ethical review by the Institutional Biosafety and Research Ethics Board of the World Vegetable Center because it posed minimal risk to study participants.

Informed Consent Statement: Informed consent was obtained from all subjects involved in the study.

Data Availability Statement: The data presented in this study are openly available in the World Vegetable Centers online repository "Harvest" at https:/ / doi.org/10.22001/wvc.74139, record ID 74139.

Acknowledgments: We are grateful for the time and effort provided by all farmers, hired workers and other informants we interviewed, in Myanmar and Bangladesh. We thank all students and staff involved in the data collection for their hard work. We thank AKM Mahbubul Alam of the Bangladesh Agricultural Research Institute (BARI) for his administration of the project in Bangladesh and we thank Abdur Rashid of BARI and Mohammad Mizanul Haque Kazal of Sher-e-Bangla University and his team for their contribution to the qualitative research.

Conflicts of Interest: The authors declare no conflict of interest. The funders had no role in the design of the study; in the collection, analyses, or interpretation of data; in the writing of the manuscript, or in the decision to publish the results.

\section{Appendix A}

Table A1. Association between frequency of harvests and the labor requirement.

\begin{tabular}{|c|c|c|}
\hline & \multicolumn{2}{|c|}{ Ln. of Labor Hours Spent on Harvest Per Ha } \\
\hline & Coeff. & SE \\
\hline \multicolumn{3}{|l|}{ Number of harvests (Base: 1 harvest) } \\
\hline-2 harvests & $0.350 * * *$ & $(0.081)$ \\
\hline-3 harvests & $0.761^{* * *}$ & $(0.096)$ \\
\hline - 4 harvests & $0.967 * * *$ & $(0.139)$ \\
\hline - 5 harvests & 0.572 & $(0.477)$ \\
\hline Ln. of planted area, ha & $-0.195^{* * *}$ & $(0.039)$ \\
\hline Ln. of planted area, squared & $0.049^{* * *}$ & $(0.013)$ \\
\hline Ln. of days crop stayed in the field & $0.485 *$ & $(0.254)$ \\
\hline \multicolumn{3}{|l|}{ Season (Base: Pre-monsoon) } \\
\hline - Winter & -0.269 & $(0.186)$ \\
\hline — Monsoon & $-0.498^{* * *}$ & $(0.109)$ \\
\hline \multicolumn{3}{|l|}{ Region (Base: Magway) } \\
\hline —-Sagaing & $-0.189 *$ & $(0.114)$ \\
\hline - Bago & 0.045 & $(0.181)$ \\
\hline - Yangon & 0.064 & $(0.185)$ \\
\hline - Natore & $-0.643^{* * *}$ & $(0.160)$ \\
\hline - Jhenaidah & $-0.656^{* * *}$ & $(0.154)$ \\
\hline - Pabna & $-0.597^{* * *}$ & $(0.178)$ \\
\hline Constant & $3.250 * * *$ & $(1.076)$ \\
\hline Observations & 825 & \\
\hline $\mathrm{R} 2$ & 0.285 & \\
\hline \multicolumn{3}{|c|}{$\begin{array}{l}\text { Note: Ordinary least squares regression. Sample excludes farmers using combine harvesters in the mungb } \\
\text { harvest. Robust standard errors in parentheses, }{ }^{*} p<0.10,{ }^{* * *} p<0.01 .\end{array}$} \\
\hline & Coefficient & SE \\
\hline \multicolumn{3}{|l|}{ Number of harvests (Base: 1 harvest) } \\
\hline-2 harvests & $135.59 * * *$ & $(49.64)$ \\
\hline-3 harvests & $324.55^{* * *}$ & $(63.34)$ \\
\hline - 4 harvests & $306.92 * * *$ & $(98.90)$ \\
\hline-5 harvests & $526.45^{* *}$ & $(204.88)$ \\
\hline Planted area, ha & -6.54 & $(13.15)$ \\
\hline Planted area, squared & 0.13 & $(0.42)$ \\
\hline
\end{tabular}


Table A2. Cont.

\begin{tabular}{ccc}
\hline & Coefficient & SE \\
\hline Days of crop in the field & $33.68^{* * *}$ & $(12.15)$ \\
Days of the crop in the field, squared & $-0.18^{* * *}$ & $(0.07)$ \\
Fertilizer expenditure, USD/ha & -0.00 & $(0.00)$ \\
Fertilizer expenditure, squared & 0.00 & $(0.00)$ \\
Pesticide expenditure, USD/ha & $0.00^{* * *}$ & $(0.00)$ \\
Pesticide expenditure, squared & -0.00 & $(0.00)$ \\
Region (Base: Magway) & & \\
- Sagaing & $173.85^{* * *}$ & $(65.01)$ \\
- Bago & $317.92^{* * *}$ & $(71.48)$ \\
- Yangon & $304.02^{* * *}$ & $(69.57)$ \\
- Natore & $333.52^{* * *}$ & $(71.46)$ \\
- Jhenaidah & $846.93^{* * *}$ & $(77.90)$ \\
- Pabna & $439.38^{* * *}$ & $(507.23)$ \\
Constant & $-1202.37^{* *}$ & \\
Observations & 868 & \\
$\mathrm{R}^{2}$ & 0.330 &
\end{tabular}

Note: Ordinary least squares regression. Each observation represents a season with mungbean production of the 828 farmers who are not using combine harvesters in the mungbean production. Robust standard errors in parentheses, ${ }^{* *} p<0.05,{ }^{* * *} p<0.01$.

Table A3. Association between frequency of harvests and the share of the second and third harvest in total yield.

\begin{tabular}{|c|c|c|c|c|}
\hline & \multicolumn{2}{|c|}{$\begin{array}{c}\text { Proportion of Yield Produced in } \\
\text { Second Harvest }\end{array}$} & \multicolumn{2}{|c|}{$\begin{array}{c}\text { Proportion of Yield Produced in } \\
\text { Third Harvest }\end{array}$} \\
\hline & Coef. & SE & Coef. & SE \\
\hline \multicolumn{5}{|l|}{ Number of harvests } \\
\hline-3 harvests & $-0.036^{* * *}$ & $(0.013)$ & - & - \\
\hline - 4 harvests & $-0.103^{* * *}$ & $(0.020)$ & 0.010 & $(0.015)$ \\
\hline - 5 harvests & $-0.185^{* * *}$ & $(0.043)$ & -0.039 & $(0.032)$ \\
\hline Planted area, ha & 0.005 & $(0.004)$ & -0.008 & $(0.009)$ \\
\hline Planted area, squared & $-0.000 *$ & $(0.000)$ & 0.001 & $(0.001)$ \\
\hline Days of crop in the field & -0.000 & $(0.005)$ & $0.010^{* *}$ & $(0.004)$ \\
\hline Days of the crop in the field, squared & 0.000 & $(0.000)$ & $-0.000^{* *}$ & $(0.000)$ \\
\hline Fertilizer expenditure, USD/ha & $-0.000^{* *}$ & $(0.000)$ & -0.000 & $(0.000)$ \\
\hline Fertilizer expenditure, squared & 0.000 & $(0.000)$ & 0.000 & $(0.000)$ \\
\hline Pesticide expenditure, USD/ha & $-0.000 *$ & $(0.000)$ & -0.000 & $(0.000)$ \\
\hline Pesticide expenditure, squared & 0.000 & $(0.000)$ & 0.000 & $(0.000)$ \\
\hline \multicolumn{5}{|l|}{ Region (Base: Magway) } \\
\hline _- Sagaing & 0.012 & $(0.014)$ & 0.013 & $(0.013)$ \\
\hline - Bago & $-0.072^{* *}$ & $(0.029)$ & -0.044 & $(0.038)$ \\
\hline - Yangon & $-0.184^{* * *}$ & $(0.022)$ & $-0.092^{* * *}$ & $(0.026)$ \\
\hline - Natore & $0.075^{* * *}$ & $(0.020)$ & 0.000 & $(0.017)$ \\
\hline — Jhenaidah & $0.087^{* * *}$ & $(0.021)$ & 0.015 & $(0.018)$ \\
\hline - Pabna & 0.020 & $(0.022)$ & 0.009 & $(0.019)$ \\
\hline Constant & 0.387 * & $(0.217)$ & -0.260 & $(0.177)$ \\
\hline Observations & 693 & & 397 & \\
\hline $\mathrm{R}^{2}$ & 0.332 & & 0.087 & \\
\hline
\end{tabular}

Note: Ordinary least squares regression. Each observation represents a season with mungbean production with $\geq 2$ and $\geq 3$ harvests, respectively. Excludes farmers using combine harvesters in the mungbean harvest. Robust standard errors in parentheses, ${ }^{*} p<0.10$, ${ }^{* *} p<0.05,{ }^{* * *} p<0.01$.

\section{References}

1. Mrema, G.; Soni, P.; Rolle, R.S. A Regional Strategy for Sustainable Agricultural Mechanization. Sustainable Mechanization across Agri-Food Chains in Asia and the Pacific Region; FAO Regional Office for Asia and the Pacific: Bangkok, Thailand, 2014.

2. Biggs, S.; Justice, S.E. Rural and agricultural mechanization: A history of the spread of small engines in selected asian countries. In IFPRI Discussion Paper; International Food Policy Research Institute (IFPRI): Washington, DC, USA, 2015. 
3. Daum, T.; Birner, R. Agricultural mechanization in Africa: Myths, realities and an emerging research agenda. Glob. Food Secur. 2020, 26, 100393. [CrossRef]

4. Deininger, K.W.; Byerlee, D.; World Bank. Rising Global Interest in Farmland: Can It Yield Sustainable and Equitable Benefits? World Bank: Washington, DC, USA, 2011; 214p.

5. Zhang, X.; Rashid, S.; Ahmad, K.; Ahmed, A. Escalation of Real Wages in Bangladesh: Is it the Beginning of Structural Transformation? World Dev. 2014, 64, 273-285. [CrossRef]

6. Rigg, J.; Salamanca, A.; Thompson, E.C. The puzzle of East and Southeast Asia's persistent smallholder. J. Rural Stud. 2016, 43, 118-133. [CrossRef]

7. Davis, B.; Di Giuseppe, S.; Zezza, A. Are African households (not) leaving agriculture? Patterns of households' income sources in rural Sub-Saharan Africa. Food Policy 2017, 67, 153-174. [CrossRef] [PubMed]

8. Paris, T.R.; Chi, T.T.N. The Impact of Row Seeder Technology on Women Labor: A Case Study in the Mekong Delta, Vietnam. Gender Technol. Dev. 2005, 9, 157-184. [CrossRef]

9. Singh, S.; Sinwal, S.; Rathore, H. Assessment of energy balance of Indian farm women in relation to their nutritional profile in lean and peak agricultural seasons. Work 2012, 41, 4363-4371. [CrossRef]

10. Nichols, C.E. Time Ni Hota Hai: Time poverty and food security in the Kumaon hills, India. Gender Place Cult. 2016, 23, 1404-1419. [CrossRef]

11. International Labour Office. World Employment and Social Outlook: Trends 2020; ILO: Geneva, Switzerland, 2020.

12. Pingali, P. Agricultural Mechanization: Adoption Patterns and Economic Impact. In Handbook of Agricultural Economics; Evenson, R., Pingali, P., Eds.; Elsevier: Amsterdam, The Netherlands, 2007; Volume 3, pp. 2779-2805.

13. Schmitz, A.; Moss, C.B. Mechanized agriculture: Machine adoption, farm size, and labor displacement. AgBioForum 2015, $18,278-296$.

14. Kawarazuka, N.; Duong, T.M.; Simelton, E. Gender, labor migration and changes in small-scale farming on Vietnam's north-central coast. Crit. Asian Stud. 2020, 52, 550-564. [CrossRef]

15. Raihan, S.; Bidisha, S.H. Female Employment Stagnation in Bangladesh; The Asia Foundation: San Francisco, CA, USA, 2018.

16. Htway, S.S.; Phyo, A.S.; Grunbuhel, C.M. Impacts of Rural Changes on Women Labor Involvement in Agriculture of Myanmar. In Proceedings of the SEAGA International Conference 2017, Jakarta, Indonesia, 28 November-1 December 2017.

17. Farnworth, C.R.; San, A.M.; Kundu, N.D.; Islam, M.M.; Jahan, R.; Depenbusch, L.; Nair, R.M.; Myint, T.; Schreinemachers, P. How Will Mechanizing Mung Bean Harvesting Affect Women Hired Laborers in Myanmar and Bangladesh? Sustainability 2020, 12, 7870. [CrossRef]

18. Theis, S.; Krupnik, T.J.; Sultana, N.; Rahman, S.-U.; Seymour, G.; Abedin, N. Gender and Agricultural Mechanization: A MixedMethods Exploration of the Impacts of Multi-Crop Reaper-Harvester Service Provision in Bangladesh; International Food Policy Research Institute: Washington, DC, USA, 2019; Volume 1837.

19. Phyo, S.A.; Grünbühel, C.; Williams, L.; Htway, S.S. Changing Dynamics in Rural Myanmar: Non-farm Development, Agricultural Labor Shortages and Farm Mechanization. In ACIAR Mid-Term Research Conference; Yezin Agricultural University: Yezin, Myanmar, 2016.

20. Sraboni, E.; Quisumbing, A.R.; Ahmed, A.U. How Empowered are Bangladeshi Women in the Agricultural Setting? Empirical Evidence using a New Index. Bangladesh Dev. Stud. 2014, 37, 1-25. [CrossRef]

21. Schreinemachers, P.; Sequeros, T.; Rani, S.; Rashid, M.A.; Gowdru, N.V.; Rahman, M.S.; Ahmed, M.R.; Nair, R.M. Counting the beans: Quantifying the adoption of improved mungbean varieties in South Asia and Myanmar. Food Secur. 2019, 11, 623-634. [CrossRef]

22. Foyer, C.H.; Lam, H.-M.; Nguyen, H.T.; Siddique, K.H.M.; Varshney, R.K.; Colmer, T.D.; Cowling, W.; Bramley, H.; Mori, T.A.; Hodgson, J.M.; et al. Neglecting legumes has compromised human health and sustainable food production. Nat. Plants 2016, 2, 16112. [CrossRef] [PubMed]

23. Barton, L.; Thamo, T.; Engelbrecht, D.; Biswas, W.K. Does growing grain legumes or applying lime cost effectively lower greenhouse gas emissions from wheat production in a semi-arid climate? J. Clean. Prod. 2014, 83, 194-203. [CrossRef]

24. Springmann, M.; Clark, M.; Mason-D'Croz, D.; Wiebe, K.; Bodirsky, B.L.; Lassaletta, L.; de Vries, W.; Vermeulen, S.J.; Herrero, M.; Carlson, K.M.; et al. Options for keeping the food system within environmental limits. Nature 2018, 562, 519-525. [CrossRef] [PubMed]

25. Nair, R.M.; Schreinemachers, P. Global Status and Economic Importance of Mungbean. In The Mungbean Genome. Compendium of Plant Genomes; Nair, R.M., Schafleitner, R., Lee, S.-H., Eds.; Springer: Cham, Switzerland, 2020. [CrossRef]

26. Sequeros, T.; Schreinemachers, P.; Depenbusch, L.; Shwe, T.; Nair, R.M. Impact and returns on investment of mungbean research and development in Myanmar. Agric. Food Secur. 2020, 9, 5. [CrossRef]

27. Mottaleb, K.A.; Krupnik, T.J.; Erenstein, O. Factors associated with small-scale agricultural machinery adoption in Bangladesh: Census findings. J. Rural Stud. 2016, 46, 155-168. [CrossRef]

28. Justice, S.; Biggs, S. The spread of smaller engines and markets in machinery services in rural areas of South Asia. J. Rural Stud. 2020, 73, 10-20. [CrossRef]

29. Belton, B.; Filipski, M. Rural transformation in central Myanmar: By how much, and for whom? J. Rural Stud. 2019, 67, 166-176. [CrossRef] 
30. Win, M.T.; Thinzar, A.M. Agricultural Mechanizationa and Structural Transformation in Myanmar's Ayerwady Delta; IFPRI: Washington, DC, USA, 2016.

31. Ahmed, A.U. Patterns of Farm Mechanisation in Bangladesh. In Rural Mechanisation: A Driver in Agricultural Change and Rural Development; Mandal, S.M.A., Biggs, S.D., Justice, S.E., Eds.; Institute for Inclusive Finance and Development: Dhaka, Bangladesh, 2017.

32. Fischer, G.; Wittich, S.; Malima, G.; Sikumba, G.; Lukuyu, B.; Ngunga, D.; Rugalabam, J. Gender and mechanization: Exploring the sustainability of mechanized forage chopping in Tanzania. J. Rural Stud. 2018, 64, 112-122. [CrossRef]

33. Van Eerdewijk, A.; Danielsen, K. Gender Matters in Farm Power; KIT Royal Tropical Institute: Amsterdam, The Netherlands, 2015.

34. Sims, B.; Kienzle, J. Making Mechanization Accessible to Smallholder Farmers in Sub-Saharan Africa. Environments 2016, 3, 11. [CrossRef]

35. Gulati, K.; Ward, P.S.; Lybbert, T.J.; Spielman, D.J. Intrahousehold preference heterogeneity and demand for labor-saving agricultural technology: The case of mechanical rice transplanting in India. In IFPRI Discussion Paper; International Food Policy Research Institute (IFPRI): Washington, DC, USA, 2019; Volume 1880.

36. Adu-Baffour, F.; Daum, T.; Birner, R. Can small farms benefit from big companies' initiatives to promote mechanization in Africa? A case study from Zambia. Food Policy 2019, 84, 133-145. [CrossRef]

37. Paudel, G.P.; Gartaula, H.; Rahut, D.B.; Craufurd, P. Gender differentiated small-scale farm mechanization in Nepal hills: An application of exogenous switching treatment regression. Technol. Soc. 2020, 61, 101250. [CrossRef] [PubMed]

38. Chi, T.T.N. Factors Affecting Mechanization in Rice Harvesting and Drying in the Mekong Delta, South Vietname. Omonrice 2010, $17,164-173$.

39. Johnson, N.L.; Kovarik, C.; Meinzen-Dick, R.; Njuki, J.; Quisumbing, A. Gender, Assets, and Agricultural Development: Lessons from Eight Projects. World Dev. 2016, 83, 295-311. [CrossRef]

40. Khatri-Chhetri, A.; Chanana, N. Women's groups reaping the benefits of solar energy for irrigation in Nepal's Climate-Smart Villages. In CSALP South Asia Quarterly Newsletter; CGIAR Research Program on Climate Change, Agriculture and Food Security (CCAFS): New Delhi, India, 2017.

41. Orr, A.; Tsusaka, T.; Kee-Tui, S.H.; Msere, H. What Do We Mean by 'Women's Crops'? Commercialisation, Gender and the Power to Name. J. Int. Dev. 2016, 28, 919-937. [CrossRef]

42. Mueller, V.; Schmidt, E.; Kirkleeng, D. Structural Change and Women's Employment Potential in Myanmar. Int. Reg. Sci. Rev. 2020, 43, 450-476. [CrossRef]

43. Afridi, F.; Bishnu, M.; Mahajan, K. Gendering Technological Change: Evidence from Agricultural Mechanization. In IZA Discussion Paper Series; IZA-Institute of Labor Economics: Bonn, Germany, 2020.

44. Pattnaik, I.; Lahiri-Dutt, K.; Lockie, S.; Pritchard, B. The feminization of agriculture or the feminization of agrarian distress? Tracking the trajectory of women in agriculture in India. J. Asia Pac. Econ. 2018, 23, 138-155. [CrossRef]

45. Bouwman, T.I.; Andersson, J.A.; Giller, K.E. Herbicide Induced Hunger? Conservation Agriculture, Ganyu Labour and Rural Poverty in Central Malawi. J. Dev. Stud. 2020. [CrossRef]

46. Central Statistical Organization. Myanmar Statistical Yearbook 2018; Central Statistical Organization: Nay Pyi Taw, Myanmar, 2018.

47. Bangladesh Bureau of Statistics. Yearbook of Agricultural Statistics-2019; Bangladesh Bureau of Statistics: Dhaka, Bangladesh, 2020.

48. Schober, J. Modern Buddhist Conjunctures in Myanmar: Cultural Narratives, Colonial Legacies, and Civil Society; University of Hawaii Press: Honolulu, HI, USA, 2011.

49. Dove, C. Giving Trends in Myanmar: More Than Merit Making. Austrian J. South-East Asian Stud. 2017, 10, 205-222. [CrossRef]

50. Adkins, W.G.; Metzler, W.H. Tenure and Mechanization of the Cotton Harvest, Texas High Plains. Texas Agric. Exp. Stn. Bull. 1955, 813, 3-15.

51. Woldu, T.; Tadesse, F.; Waller, M.-K. Women's participation in agricultural cooperatives in Ethiopia. In ESSP II Working Paper; International Food Policy Research Institute (IFPRI) and Ethiopian Development Research Institute (EDRI): Washington, DC, USA, 2013.

52. Cole, S.M.; Kantor, P.; Sarapura, S.; Rajaratnam, S. Gender-Transformative Approaches to Address Inequalities in Food, Nutrition and Economic Outcomes in Aquatic Agricultural Systems; CGIAR Research Program on Aquati Agricultural Systems: Penang, Malaysia, 2014; Volume AAS-2014-42.

53. Edström, J.; Izugbara, C.; Nesbitt-Ahmed, Z.; Otieno, P.E.; Granvik, M.; Matindi, S. Men in Collective Action on SGBV in Kenya: A Case Study; IDS: Brighton, UK, 2014; Volume 70.

54. Farnworth, C.R.; Stirling, C.M.; Chinyophiro, A.; Namakhoma, A.; Morahan, R. Exploring the potential of household methodologies to strengthen gender equality and improve smallholder livelihoods: Research in Malawi in maize-based systems. J. Arid Environ. 2018, 149, 53-61. [CrossRef]

55. Farnworth, C.R.; Kantor, P.; Kruijssen, F.; Longley, C.; Colverson, K.E. Gender integration in livestock and fisheries value chains: Emerging good practices from analysis to action. Int. J. Agri. Resour. Govern. Ecol. 2015, 11, 262-279. [CrossRef]

56. Farnworth, C.R.; Jafry, T.; Rahman, S.; Badstue, L.B. Leaving no one behind: How women seize control of wheat-maize technologies in Bangladesh. Can. J. Dev. Stud./Rev. Can. d'études Développement 2020, 41, 20-39. [CrossRef] [PubMed]

57. Dietz, M. Access for women-Building up a system of rural private service providers. Rural 2019, 21, 28-30. 